\title{
KNOWLEDGE SHARING SYSTEM BERBASIS WEB (STUDI KASUS: PDAM TIRTA MUSI PALEMBANG)
}

\author{
Rian Pratama1, Ruliansyah ${ }^{2}$, Muhamad Kadafi $^{3}$, Catur E Gunawan ${ }^{4}$ \\ 1,2,3,4 Universitas Islam Negeri Raden Fatah Palembang - Indonesia \\ Email: ${ }^{1}$ rian.pratama0031@gmail.com, ${ }^{2}$ ruli@radenfatah.ac.id, ${ }^{3}$ kadafi_uin@ @adenfatah.ac.id, \\ ${ }^{4}$ caturerig@radenfatah.ac.id
}

(Naskah masuk: 19 Oktober 2020, diterima untuk diterbitkan: 18 November 2020)

\begin{abstract}
Abstrak
Perusahaan Daerah Air Minum (PDAM) Tirta Musi Palembang adalah perusahaan yang bergerak di bidang pelayanan penyediaan air minum kepada masyarakat kota Palembang. Perusahaan menyadari pentingnya sebuah pengelolaan dan pendokumentasian pengetahuan karyawan bagi keberlangsungan perusahaan. Saat ini pengetahuan para karyawan yang ada di PDAM Tirta Musi Palembang belum dapat terdistribusi dengan baik sehingga berdampak pada pemanfaatan pengetahuan yang kurang efektif. Knowledge Sharing System merupakan alat yang dapat membantu dalam mendokumentasikan serta mendistribusikan pengetahuan karyawan sehingga dapat terjadi proses berbagi pengetahuan antar karyawan. Tujuan dari penelitian ini adalah membangun Knowledge Sharing System yang dapat dimanfaatkan untuk mendokumentasikan serta mendistribusikan pengetahuan karyawan. Metode pengembangan sistem yang digunakan pada pengembangan Knowledge Sharing System ini adalah menggunakan metode Web Engineering. Metode ini seringkali digunakan untuk pengembangan perangkat lunak berbasis web. Hasil dari penelitian ini adalah telah dibangun sebuah Knowledge Sharing System berbasis web yang telah diuji dengan menggunakan metode Black Box testing dan telah diimplementasikan pada PDAM Tirta Musi Palembang yang digunakan untuk membantu dalam pengelolaan dan pendokumentasian pengetahuan karyawan.
\end{abstract}

Kata kunci: Knowledge Sharing System, berbasis Web, Web Engineering

\section{WEB-BASED KNOWLEDGE SHARING SYSTEM (CASE STUDY: PDAM TIRTA MUSI PALEMBANG)}

\begin{abstract}
Perusahaan Daerah Air Minum (PDAM) Tirta Musi Palembang is a company engaged in providing mineral water services to the people of Palembang city. The company realizes the importance of managing and documenting employee knowledge for the sustainability of the company. Currently, the knowledge of employees at PDAM Tirta Musi Palembang has not been distributed properly, thus resulting in the ineffective utilization of this knowledge. The Knowledge Sharing System is a tool that can assist in documenting and distributing employee knowledge so that knowledge sharing can occur between employees. The purpose of this research is to build a Knowledge Sharing System that can be used to document and distribute employee knowledge. The system development method used in the Knowledge Sharing System is the Web Engineering method. This method is often used for web-based software development. The result of this research is that a web-based Knowledge Sharing System has been built which has been tested using the Black Box testing method and has been implemented at PDAM Tirta Musi Palembang which is used to assist in the management and documentation of employee knowledge.
\end{abstract}

Keywords: Knowledge Sharing System, Web-based, Web Engineering

\section{PENDAHULUAN}

Pengelolaan informasi di dalam suatu perusahaan merupakan hal yang sangat penting untuk dilakukan. Dengan memanfaatkan teknologi, tentunya informasi akan mudah untuk dikelola dan dengan cepat dapat dibagikan dan disebarluaskan. Penggunaan teknologi dibutuhkan dalam membantu aktivitas pekerjaan[1] dan memudahkan dalam pengolahan data yang dihasilkan oleh sistem[2]. Tidak kalah penting juga apabila dibandingkan dengan informasi, perusahaan juga perlu mengelola pengetahuan (knowledge) yang secara tidak disadari merupakan aset yang berharga bagi perusahaan. Pengelolaan pengetahuan (knowledge management) 
dibangun dengan tujuan untuk meningkatkan performa seseorang ataupun perusahaan dengan cara mengelola dan menyediakan sumber pengetahuan (knowledge) yang ada saat ini dan untuk masa yang akan datang[3]. Perusahaan Daerah Air Minum (PDAM) Tirta Musi Palembang merupakan perusahaan Badan Usaha Milik Daerah (BUMD) yang saat ini mulai memperhatikan pentingnya pengelolaan pengetahuan karyawan. PDAM Tirta Musi Palembang merupakan perusahaan di bidang pelayanan penyedia air minum masyarakat Kota Palembang. Perusahaan menyadari pentingnya pengelolaan pengetahuan karyawan, dikutip dari Rakhmawati menyebutkan bahwa pengetahuan karyawan saat ini juga merupakan aset terbesar dari perusahaan[4].

Perusahaan PDAM Tirta Musi Palembang memiliki banyak karyawan yang dibagi ke dalam sejumlah divisi yang berbeda-beda sesuai dengan tugas dan fungsi mereka. Setiap tahunnya perusahaan kedatangan karyawan baru yang tersebar di berbagai divisi. Permasalahan yang terjadi saat ini adalah karyawan-karyawan baru tersebut dituntut untuk beradaptasi dengan cepat dan memahami seluruh proses bisnis perusahaan dengan baik. Karyawankaryawan baru tersebut kebanyakan masih minim pengetahuan dasar akan mengenai tugas dan fungsi sesuai divisi mereka masing-masing. Perusahaan merasa kesulitan apabila hanya berharap pada karyawan senior dalam penyampaian pengetahuan (knowledge) yang dimiliki perusahaan.

Saat ini, yang dilakukan oleh perusahan dengan memberikan workshop, seminar dan bimbingan dari karyawan senior untuk memperkaya pengetahuan serta pengalaman mereka. Hal ini tentunya bukan merupakan pilihan yang tepat, selain anggaran yang tidak sedikit untuk mengikutsertakan seluruh karyawan-karyawan tersebut juga kemungkinan untuk karyawan senior dipindahtugaskan ke wilayah lain dan pensiun sangat mungkin terjadi. Perusahaan perlu menjaga pengetahuan (knowledge) setiap karyawan tersebut untuk menjaga kinerja perusahaan. Hal ini juga tentunya akan berdampak positif pada produktivitas perusahaan[5]. Perusahaan perlu menjaga hal ini, untuk memastikan bahwa pengetahuan (knowledge) individu tersebut tidak hilang[6].

Tujuan dari penelitian ini adalah membangun Knowledge Sharing System yang dapat dimanfaatkan untuk mendokumentasikan serta mendistribusikan pengetahuan karyawan. Sistem yang akan dibangun digunakan untuk mentransfer pengetahuan yang telah ada kepada karyawan-karyawan baru. Sistem ini nantinya akan sangat berguna untuk mengelola pengetahuan yang ada. Menurut Martini bahwa apabila perusahaan bersedia untuk mengelola dan berbagi pengetahuan termasuk tacit knowledge (pengetahuan yang melekat di setiap individu) maka akan berpeluang untuk mengkolaborasikan pengetahuan tersebut untuk berkontribusi pada pertumbuhan perusahaan[7]. Metode pengembangan sistem yang digunakan Web Engineering. Metode ini menggunakan pendekatan yang sistematis sehingga memungkinkan akan tercipta sistem yang memiliki kualitas yang baik[8]. Dengan menggunakan sistem berbasis web sangat memudahkan dalam penyebarluasan informasi[9].

Pada penelitian sebelumnya terkait Knowledge Sharing System, dalam penelitian Sutrisna, dijelaskan pentingnya knowledge management untuk menghadapi perpindahan pegawai yang begitu cepat[10]. Di dalam penelitian lain, Ekadiansyah menjelaskan penting knowledge management untuk mengembangkan sumber daya manusia yang dimiliki oleh perusahaan[11]. Selain itu, Putri \& Pangaribuan memanfaatkan knowledge management untuk melakukan sharing knowledge di instansi pemerintah[12]. Di dalam artikel ini lebih difokuskan pada knowledge sharing (berbagi pengetahuan). Tidak hanya dikelola dengan baik, tetapi pengetahuan yang sudah dimiliki tersebut bisa dengan cepat dibagikan kepada karyawan baru untuk mempersiapkan mereka lebih cepat dalam memahami proses bisnis perusahaan.

\section{METODE PENELITIAN}

Pendekatan Research and Development $(R \& D)$ digunakan dalam penelitian ini. Pendekatan $R \& D$ sering digunakan untuk menghasilkan suatu produk tertentu. Dalam hal ini produk akan dibangun melalui tahapan-tahapan pengembangan sistem dan akan dilakukan uji terhadap produk yang telah jadi. Metode pengembangan sistem dalam penelitian adalah Web Engineering[13]. Terdapat beberapa tahapan yang akan dilakukan dalam penelitian ini, yaitu:

a) Costumer Communication

Pada tahap ini akan dideskripsikan sistem yang akan dibuat akan seperti apa.

b) Planning

Tahap ini biasa disebut dengan tahap perencanaan terhadap sistem yang akan dibuat. Beberapa hal dilakukan seperti penentuan fitur-fitur, penjadwalan dalam membangun sistem.

c) Modelling

Pada tahap ini dilakukan pemodelan dan desain terhadap sistem yang akan dibuat.

d) Construction

Tahap ini biasa disebut dengan tahap pembuatan sistem. Teknologi apa yang akan digunakan untuk membangun sistem berbasis web nantinya.

e) Deployment

Tahap terakhir yang dilakukan adalah penyerahan dari sistem berbasis web yang telah dibuat kepada pelanggan yang dalam hal ini merupakan karyawan yang menggunakan sistem ini nantinya.

\subsection{Identifikasi Masalah}

Permasalahan yang melandasi pembuatan Knowledge Sharing System pada perusahaan PDAM 
Tirta Musi adalah dilihat dari pentingnya dalam mendokumentasikan pengetahuan yang dimiliki para karyawan agar pengetahuan tersebut tak hanya dapat bermanfaat bagi satu individu tersebut saja namun dapat dimanfaatkan oleh individu lain sebagai bahan referensi pengetahuan.

\section{Tacit Knowledge}

Merupakan pengetahuan yang terletak di dalam pikiran (otak) atau masih melekat di dalam diri seseorang atau individu yang diperoleh melalui pengalaman selama dia bekerja. Tacit Knowledge yang akan dimasukkan ke dalam sistem adalah pengetahuan yang diperoleh karyawan dari hasil sharing dengan karyawan lain, pengetahuan yang diperoleh karyawan dari pelatihan dan pengalaman kerja serta pengetahuan yang diperoleh karyawan dengan cara mempelajari materi-materi yang berkaitan dengan pekerjaannya.

\section{Explicit Knowledge}

Merupakan segala bentuk pengetahuan yang sudah direkam atau didokumentasikan sehingga lebih mudah untuk dipelajari dan didistribusikan. Karena telah didokumentasikan sehingga memudahkan karyawan untuk mempelajari explicit knowledge tersebut. Explicit knowledge dari PDAM Tirta Musi Palembang yang akan dimasukkan ke dalam sistem adalah seperti modul di perusahaan untuk karyawan baru yang berisi deskripsi pekerjaan atau dokumentasi alur proses bisnis perusahaan, referensi materi pembelajaran terkait pekerjaan di perusahaan tersebut dan notulen yang dihasilkan dari rapat perusahaan.

\subsection{Tahapan Pembuatan Sistem}

Tahapan-tahapan yang akan dilakukan dalam membuat sistem, menggunakan metode Web Engineering.

\section{a) Customer Communication}

\section{Formulation}

Pada tahap ini akan difokuskan dalam mencari kebutuhan sistem yang akan dibuat dan diformulasikan sebagai urutan kerja. Berikut ini kebutuhan sistem yang didapatkan dari proses wawancara dan observasi awal, yaitu:

- Sistem memiliki fungsi login dan logout untuk pengguna dan dapat membedakan hak akses.

- Sistem terdapat fungsi untuk mengelola data karyawan (tambah, ubah, hapus) sehingga karyawan dapat memiliki akun masingmasing.

- Sistem dapat memungkinkan pengguna untuk mendokumentasikan pengetahuan mereka.

- Sistem dapat memungkinkan pengguna untuk menyimpan pengetahuan yang telah terdokumentasi (explicit knowledge) dan juga tacit knowledge (pengetahuan yang melekat di setiap individu).

\section{Negotiation}

Pada tahap ini akan difokuskan dalam mendapatkan data-data yang dibutuhkan, sebagai berikut:

- Data karyawan yang ada di perusahaan PDAM Tirta Musi Palembang.

- Data pengetahuan karyawan baik yang telah terdokumentasi (explicit knowledge) maupun yang masih dalam bentuk tacit knowledge.

\section{Elicitation}

Pada tahap ini fokus pada pertemuan dengan calon pengguna sistem. Kemudian membahas fitur pengguna, proses bisnis dari sistem yang akan dibuat, kendala dan masalah yang biasa terjadi dalam pengumpulan pengetahuan.

\section{b) Planning}

\section{Estimation}

Pada tahap estimasi ini terdapat 2 (dua) hal yang dibahas, yaitu:

- Waktu pengerjaan sistem ini membutuhkan waktu selama 5 bulan dengan perincian tahap komunikasi dan perencanaan membutuhkan waktu 1 (satu) bulan, tahap pemodelan membutuhkan waktu 1 bulan, tahap konstruksi, ujicoba, dan revisi membutuhkan waktu 3 bulan, Terakhir setelah sistem disetujui maka akan dilakukan serah terima.

- Estimasi biaya pengerjaan sistem tidak perlu dilakukan dikarenakan hal ini digunakan untuk keperluan penelitian.

Risk Analysis

Analisis risiko akan dibagi menjadi 3 (tiga) kategori, yaitu:

- Human risk, kebanyakan kesalahan yang terjadi dikarenakan pengguna belum mengetahui fungsi dan lupa akan fitur sistem. Beberapa pengguna yang sering melakukan kesalahan merupakan pengguna yang bukan dari latarbelakang orang yang paham teknologi/komputer.

- Product Risk, sistem yang dibuat telah mengikuti proses bisnis yang ada, akan tetapi masih terjadi error pada sistem. Hal ini apabila tidak ditanggulangi dengan cepat dan tepat maka akan memperlambat waktu pengerjaan sistem.

- Proccess Risk, banyaknya proses bisnis yang ada dan membutuhkan untuk pemahaman terhadap proses bisnis tersebut memungkinkan untuk keterlambatan dalam penyelesaian sistem. Hal ini dapat dikendalikan dengan cara membagi-bagi setiap proses bisnis yang ada sehingga mudah dipahami dan dilakukan penyelesaian per-bagian kecil dari setiap pembagian proses bisnis tersebut.

\section{Schedulling}

Pengumpulan persyaratan sampai penyelesaian sistem mulai dilakukan dari bulan Oktober 2019 hingga Februari 2020. 


\section{Monitoring}

Pada tahap ini dilakukan pengamatan dan meninjau kembali setiap tahapan yang telah selesai dikerjakan, sehingga sesuai dengan jadwal pengerjaan sistem. Hasil dari tahap ini bahwa semua proses pembuatan sistem berjalan sesuai persyaratan dan sesuai rencana.

\section{c) Modelling}

Tahap ini bertujuan untuk menggambarkan proses-proses yang merupakan persyaratan sistem. Dalam hal ini digunakan Unified Modeling Language (UML) untuk menggambarkan proses sistem. Tahap ini terdiri dari 2 (dua) bagian, yaitu:

\section{Analysis Modelling}

Tahap ini akan terbagi menjadi 4 (empat) aktivitas perancangan, yaitu:

\section{- Interaction Model}

Pada tahap ini digunakan Use Case diagram, dapat dilihat pada Gambar 1.

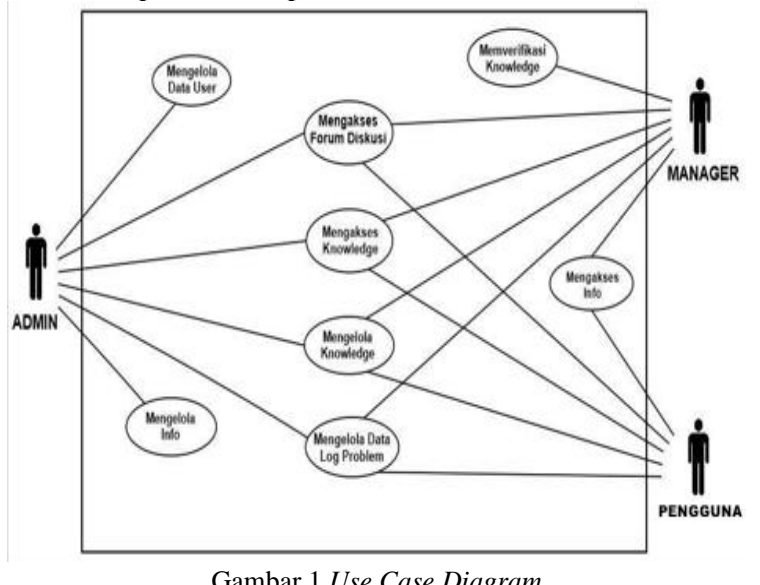

\section{- Function Model}

Tahap ini membahas elemen pemrosesan dari sistem yang akan dibuat. Digunakan activity diagram untuk menggambarkan detail dari setiap aktivitas yang ada di dalam sistem. Berikut ini sebagian aktivitas yang dilakukan dan digambarkan menggunakan activity diagram, dapat dilihat pada Gambar 2, Gambar 3, Gambar 4.

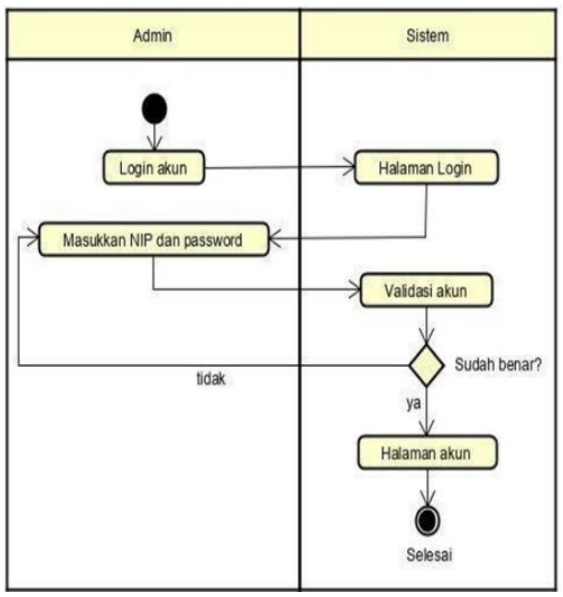

Gambar 2 Activity Diagram Login Admin

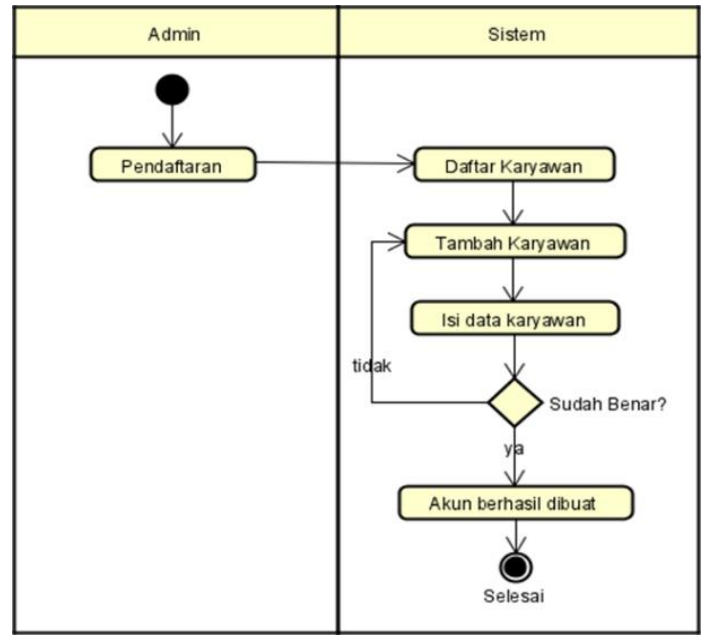

Gambar 3 Activity Diagram Pendaftaran Karyawan

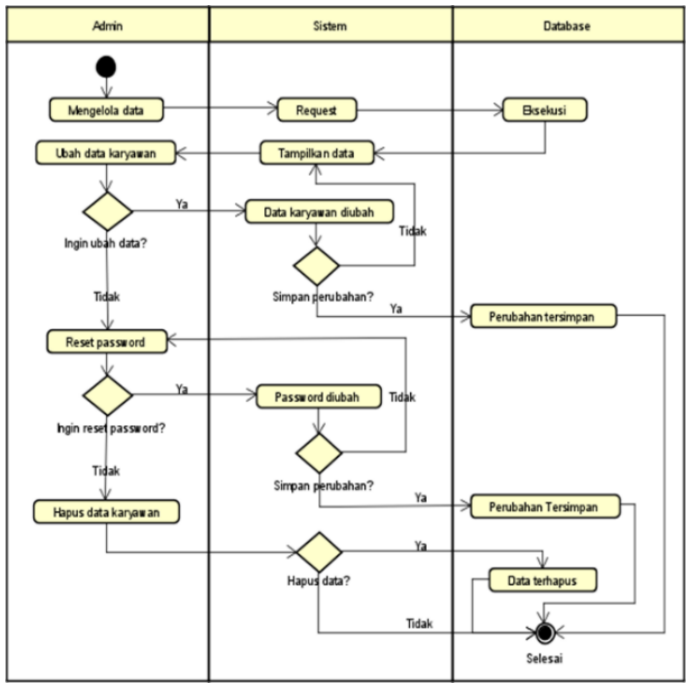

Gambar 4 Activity Diagram Kelola Data Karyawan

\section{- Content Model}

Tahap ini membahas mengenai analysis classes. Analysis classes yang dilakukan akan digambarkan ke dalam bentuk class diagram. Dapat dilihat pada Gambar 5.

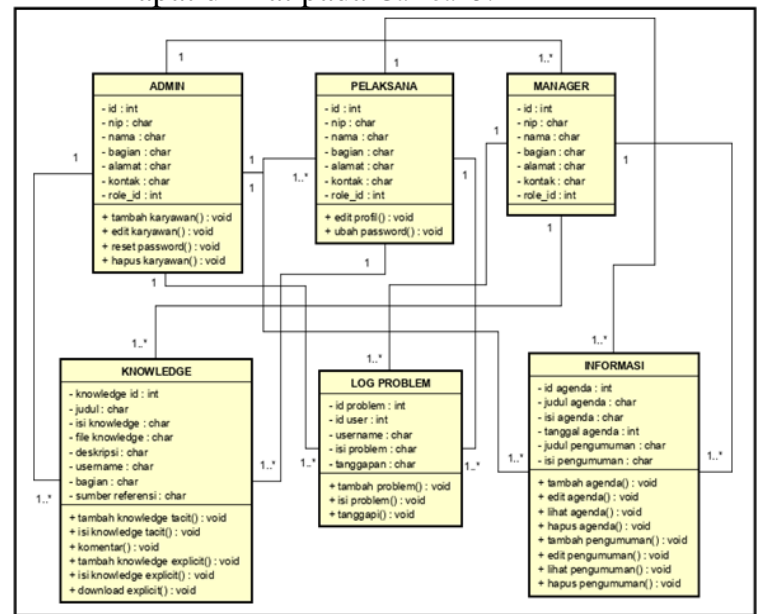

Gambar 5 Perancangan Class Diagram 


\section{Design Modelling}

Pada tahap ini akan dilakukan 2 (dua) aktivitas perancangan, yaitu:

\section{- Navigation Design}

Navigation design digambarkan berdasarkan pengguna sistem. Berikut ini sebagian dari desain yang telah dibuat, dapat dilihat pada Gambar 6.

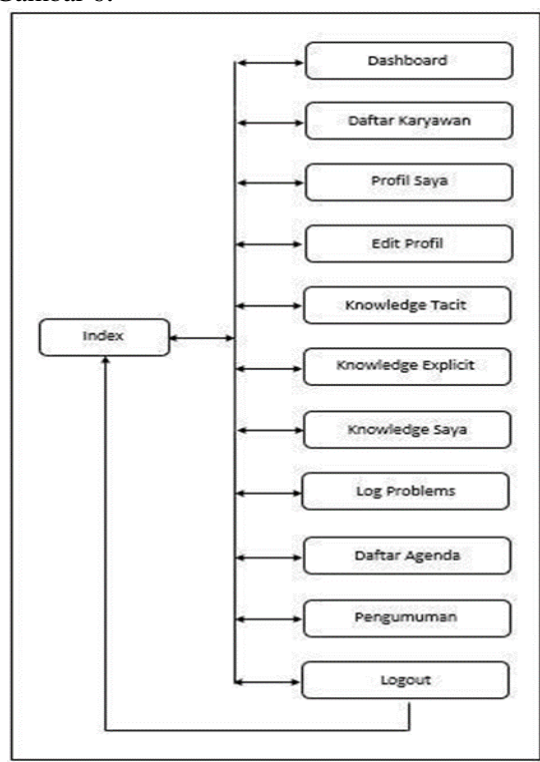

Gambar 6 Struktur Navigasi Halaman Admin

\section{- User Interface Design}

Pada tahap ini membahas mengenai perancangan antarmuka pengguna. Perancangan antarmuka (user interface) dilakukan dengan tujuan untuk mempermudah pengguna dalam menggunakan sistem berbasis web[14]. Berikut ini sebagian perancangan antarmuka yang telah dilakukan, dapat dilihat pada Gambar 7, Gambar 8.

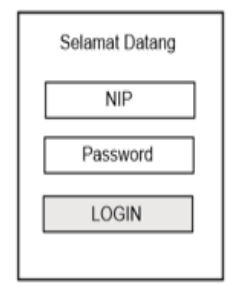

Gambar 7 Perancangan Antarmuka Halaman Login

\begin{tabular}{|c|c|c|c|c|c|c|}
\hline ADMIN & \multicolumn{5}{|c|}{ KNOWLEDGE SHARING SYSTEM } & Nama Akun \\
\hline AOMN & \multicolumn{5}{|c|}{ Dashboard } & \\
\hline O Daftar Karyawan & \multirow{3}{*}{\multicolumn{2}{|c|}{$\begin{array}{l}\text { KNOWLEDGE TACIT } \\
10 \text { BUAH }\end{array}$}} & \multirow{2}{*}{\multicolumn{2}{|c|}{$\begin{array}{l}\text { KNOWLEDGE EXPLCIT } \\
10 \text { BUAH }\end{array}$}} & \multirow{3}{*}{$\begin{array}{l}\text { G PROBLEMS } \\
\text { BUAH }\end{array}$} & \\
\hline AKUN & & & & & & \\
\hline O Profill Saya & & & & & & \\
\hline O Edit Profil & No & BAGIN & TACIT & Expucr & LOG PROBLEMS & \\
\hline KNOWLEDOE & 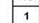 & $x \mathrm{xx}$ & $x \mathrm{xx}$ & $x \mathrm{xx}$ & $x \mathrm{xx}$ & \\
\hline O Knowledge Tacit & 2 & $\mathrm{xxx}$ & $x x x$ & $\mathrm{xxx}$ & $x \mathrm{xx}$ & \\
\hline O Knomedoge Explact & 3 & $x \mathrm{xx}$ & $x \mathrm{xx}$ & $\mathrm{xxx}$ & $x \mathrm{xx}$ & \\
\hline O Knowledge Saya & 4 & $\frac{1 x x}{x \times x}$ & $\frac{1 x x}{x x x}$ & $\mathrm{xxx}$ & $x x x$ & \\
\hline O Log roblems & & $x x x$ & $x x x$ & $x x x$ & & \\
\hline WFo & 6 & $x \mathrm{xx}$ & $x x x$ & $x x x$ & $x \mathrm{xx}$ & \\
\hline$O$ Datarta agenda & 7 & $\mathrm{xxx}$ & $x \mathrm{xx}$ & $x \mathrm{xx}$ & $x \mathrm{xxx}$ & \\
\hline OPengumuman & 8 & $x \mathrm{xx}$ & $x x x$ & $x \mathrm{xx}$ & $\mathrm{xxx}$ & \\
\hline & 9 & $x x x$ & $x x x$ & $x \mathrm{xx}$ & $x x x$ & \\
\hline
\end{tabular}

Gambar 8. Perancangan Antarmuka Halaman Utama Admin

\section{HASIL DAN PEMBAHASAN}

\subsection{Lanjutan Tahapan Metode Web Engineering}

\section{a) Construction}

\section{Implementation}

Pada tahap ini akan dibagi menjadi 3 (tiga) kategori pengguna, yaitu:

\section{- Implementasi Antarmuka Admin}

Berikut ini sebagian tampilan antarmuka admin yang telah dibuat, dapat dilihat pada Gambar 9, Gambar 10.

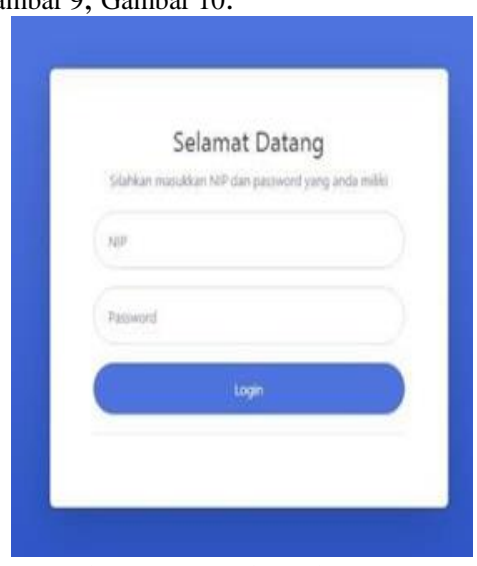

Gambar 9 Antarmuka Halaman Login

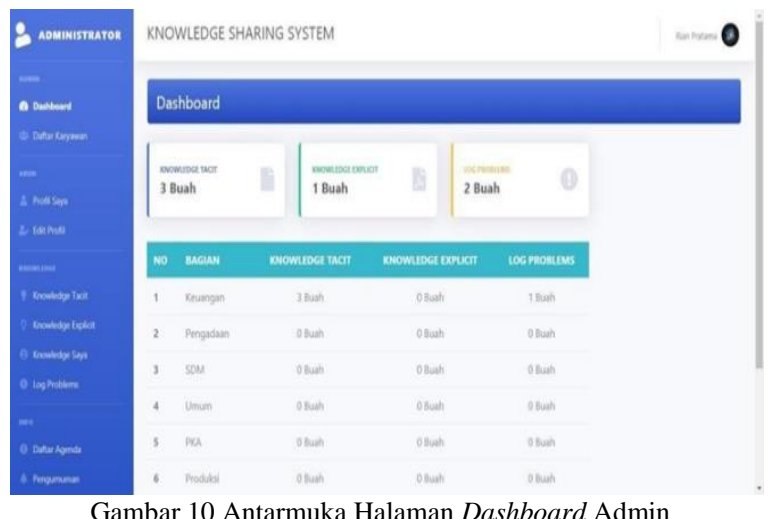

Gambar 10 Antarmuka Halaman Dashboard Admin

- Implementasi Antarmuka Pengguna

Berikut ini sebagian tampilan antarmuka pengguna yang telah dibuat, dapat dilihat pada Gambar 11, Gambar 12, Gambar 13,

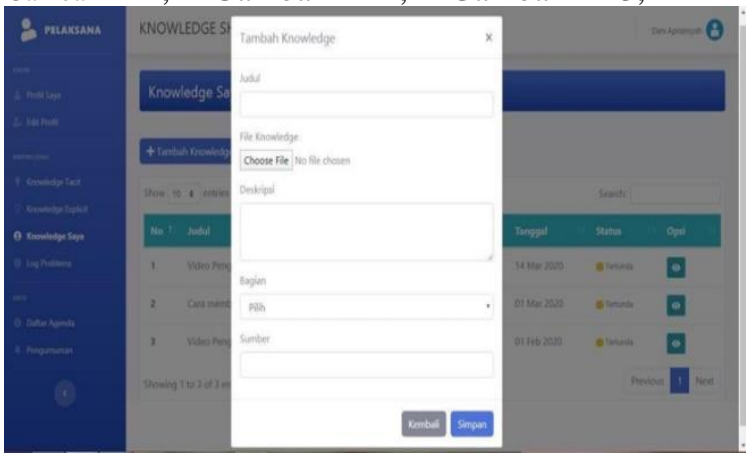

Gambar 14 


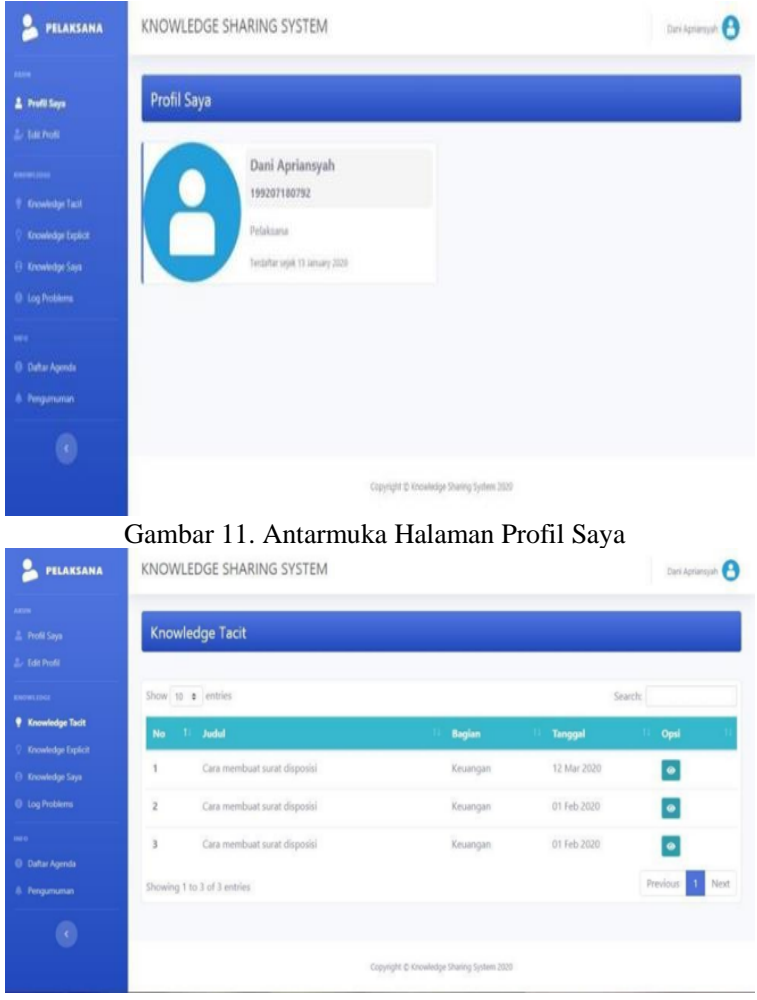

Gambar 12. Antarmuka Halaman Tacit Knowledge

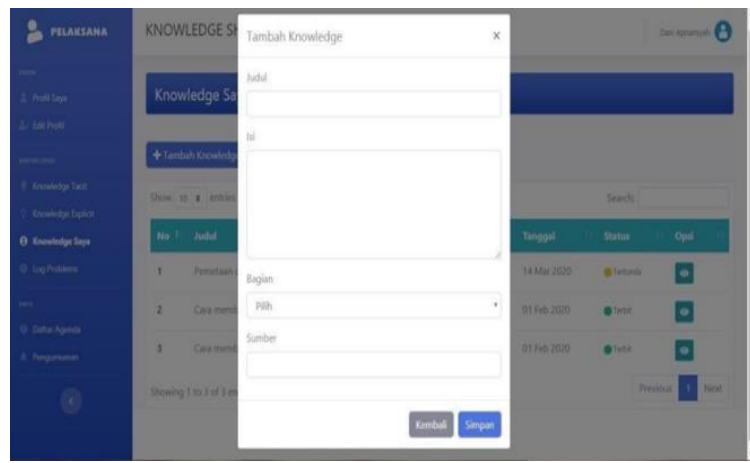

Gambar 13. Antarmuka Tambah Tacit Knowledge

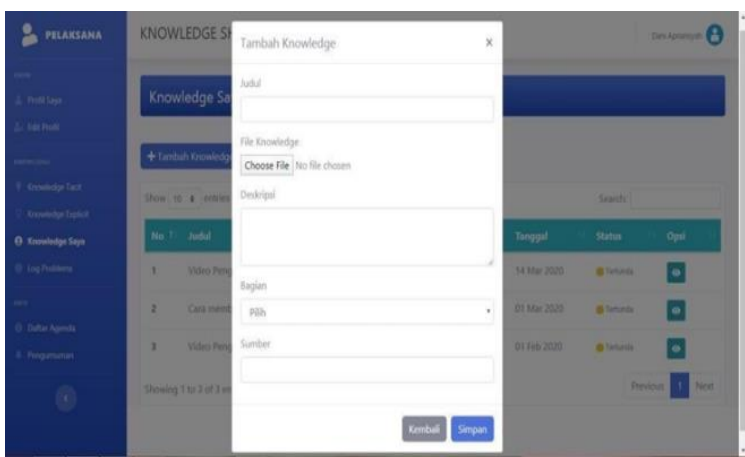

Gambar 14. Antarmuka Tambah Explicit Knowledge

\section{- Implementasi Antarmuka Manager}

Berikut ini sebagian tampilan antarmuka manager yang telah dibuat, dapat dilihat pada
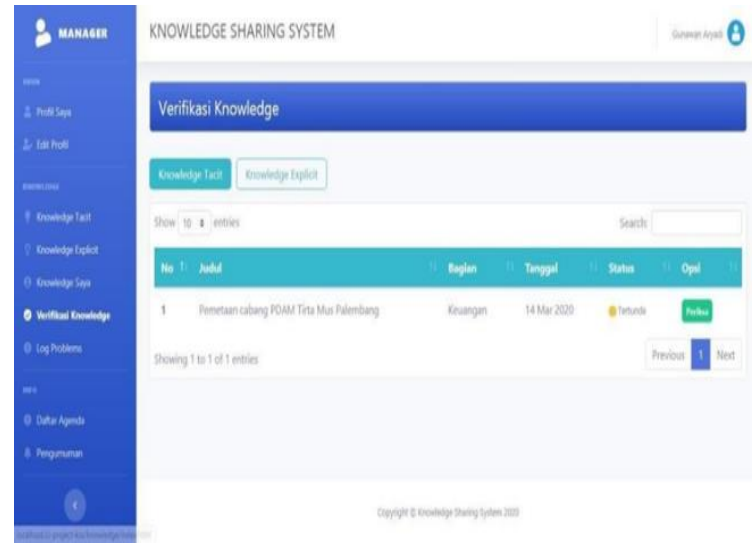

Gambar 15. Antarmuka Daftar Verifikasi Knowledge

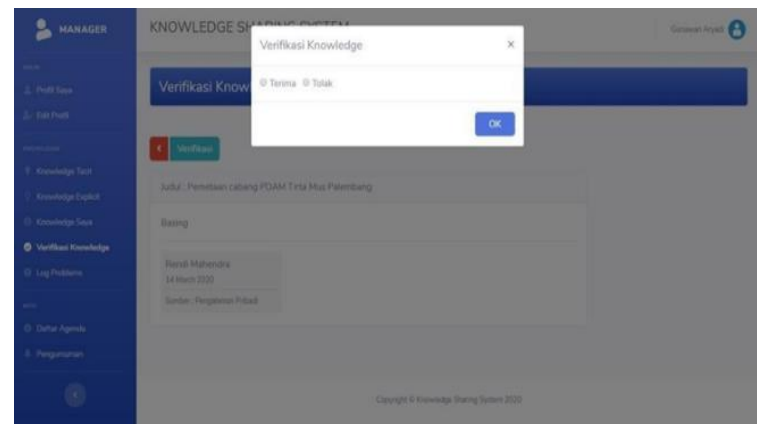

Gambar 16 Antarmuka Konfirmasi Knowledge

\section{Testing}

Pengujian yang dilakukan pada Knowledge Sharing System PDAM Tirta Musi Palembang ini menggunakan metode Black Box. Pengujian ini ditujukan untuk mengetahui apakah fungsifungsi, masukan, dan keluaran dari sistem yang dibangun sudah sesuai dengan spesifikasi yang dibutuhkan atau belum. Pada pembuatan sistem ini dilakukan sebanyak 3 (tiga) kali pengujian yang diajukan kepada Admin, Pengguna, dan Manager. Berikut ini sebagian pengujian yang dilakukan, dapat dilihat pada Tabel 1.

\begin{tabular}{|c|c|c|c|c|}
\hline No. & $\cdot \begin{array}{c}\text { Fungsi } \\
\text { yang diuji }\end{array}$ & $\begin{array}{c}\text { Cara } \\
\text { Pengujian }\end{array}$ & $\begin{array}{l}\text { Hal yang } \\
\text { diharapkan }\end{array}$ & $\begin{array}{c}\text { Hasil } \\
\text { Pengujian }\end{array}$ \\
\hline 1. & Login & $\begin{array}{l}\text { Memasukkan } \\
\text { Username dan } \\
\text { Password }\end{array}$ & $\begin{array}{l}\text { Masuk ke } \\
\text { halaman utama } \\
\text { admin }\end{array}$ & $\begin{array}{l}{[\sqrt{ }] \text { Berhasil }} \\
{[\text { ] Gagal }}\end{array}$ \\
\hline 2. & $\begin{array}{l}\text { Daftar } \\
\text { Karyawan }\end{array}$ & $\begin{array}{l}\text { Klik menu } \\
\text { Daftar } \\
\text { Karyawan }\end{array}$ & $\begin{array}{l}\text { Menampilkan } \\
\text { halaman daftar } \\
\text { karyawan }\end{array}$ & $\begin{array}{l}{[\sqrt{ }] \text { Berhasil }} \\
{[\text { ] Gagal }}\end{array}$ \\
\hline 3. & $\begin{array}{l}\text { Tambah data } \\
\text { karyawan }\end{array}$ & $\begin{array}{l}\text { Klik button } \\
\text { tambah data } \\
\text { karyawan }\end{array}$ & $\begin{array}{l}\text { Menampilkan } \\
\text { form tambah } \\
\text { data karyawan }\end{array}$ & $\begin{array}{l}{[\sqrt{ } \text { ] Berhasil }} \\
{[\text { ] Gagal }}\end{array}$ \\
\hline 4 & $\begin{array}{l}\text { Hapus data } \\
\text { karyawan }\end{array}$ & $\begin{array}{l}\text { Klik button } \\
\text { hapus }\end{array}$ & $\begin{array}{l}\text { Menampilkan } \\
\text { message } \\
\text { konfirmasi } \\
\text { hapus dan data } \\
\text { terhapus }\end{array}$ & $\begin{array}{l}{[\sqrt{ } \text { ] Berhasil }} \\
{[\text { ] Gagal }}\end{array}$ \\
\hline 5. & $\begin{array}{l}\text { Lihat data } \\
\text { karyawan }\end{array}$ & $\begin{array}{l}\text { Klik button } \\
\text { lihat }\end{array}$ & $\begin{array}{l}\text { Menampilkan } \\
\text { form berisi data } \\
\text { karyawan }\end{array}$ & $\begin{array}{l}{[\sqrt{ }] \text { Berhasil }} \\
{[\text { ] Gagal }}\end{array}$ \\
\hline 6. & $\begin{array}{l}\text { Edit data } \\
\text { karyawan }\end{array}$ & $\begin{array}{l}\text { Klik button } \\
\text { Edit Data }\end{array}$ & $\begin{array}{l}\text { Menampilkan } \\
\text { form edit data } \\
\text { karyawan }\end{array}$ & $\begin{array}{l}{[\mathrm{J} \text { Berhasil }} \\
{[\sqrt{ }] \text { Gagal }}\end{array}$ \\
\hline
\end{tabular}




\begin{tabular}{|c|c|c|c|c|}
\hline & $\begin{array}{l}\text { Reset } \\
\text { password }\end{array}$ & $\begin{array}{l}\text { Klik button } \\
\text { Reset }\end{array}$ & $\begin{array}{l}\text { Menampilkan } \\
\text { form reset }\end{array}$ & $\begin{array}{l}{[\sqrt{ }] \text { Berhasil }} \\
\text { [ ] Gagal }\end{array}$ \\
\hline & karyawan & Password & password & \\
\hline 8. & $\begin{array}{l}\text { Daftar } \\
\text { Agenda }\end{array}$ & $\begin{array}{l}\text { Klik menu } \\
\text { Daftar } \\
\text { Agenda }\end{array}$ & $\begin{array}{l}\text { Menampilkan } \\
\text { halaman daftar } \\
\text { agenda }\end{array}$ & $\begin{array}{l}{[\sqrt{ }] \text { Berhasil }} \\
{[] \text { Gagal }}\end{array}$ \\
\hline 9. & $\begin{array}{l}\text { Tambah } \\
\text { Agenda }\end{array}$ & $\begin{array}{l}\text { Klik button } \\
\text { tambah } \\
\text { agenda }\end{array}$ & $\begin{array}{l}\text { Menampilkan } \\
\text { form tambah } \\
\text { data agenda }\end{array}$ & $\begin{array}{l}{[\sqrt{ }] \text { Berhasil }} \\
{[] \text { Gagal }}\end{array}$ \\
\hline 10. & $\begin{array}{l}\text { Hapus } \\
\text { Agenda }\end{array}$ & $\begin{array}{l}\text { Klik button } \\
\text { hapus }\end{array}$ & $\begin{array}{l}\text { Menampilkan } \\
\text { message } \\
\text { konfirmasi } \\
\text { hapus dan data } \\
\text { terhapus }\end{array}$ & $\begin{array}{l}{[\sqrt{ }] \text { Berhasil }} \\
{[\quad] \text { Gagal }}\end{array}$ \\
\hline
\end{tabular}

Pada pengujian pertama Admin ini masih terdapat kegagalan sistem, oleh karena itu akan diperbaiki terlebih dahulu dan akan diujikan kembali di pengujian kedua.

Hal yang sama dilakukan pada pengujian pertama Pengguna dan pengujian pertama Manager. Pada penggujian pertama ini, seluruh pengguna dapat meminta penambahan fitur baru yang belum tersedia. Pada penelitian ini dilakukan maksimal 3 (tiga) kali pengujian sistem.

Tahapan ini merupakan tahapan yang paling lama. Inti dari tahapan ini melakukan pengujian terhadap sistem yang telah dibuat dan memastikan bahwa di pengujian terakhir semua fungsi sudah dapat digunakan dengan baik dan tidak gagal.

b) Deployment

Deployment merupakan tahapan terakhir dalam metode pengembangan sistem Web Engineering. Sistem yang telah diuji sebelumnya dan siap digunakan akan diserahkan kepada pihak yang perusahaan yang dalam hal ini adalah PDAM Tirta Musi Palembang.

\section{KESIMPULAN}

Dari penelitian ini telah menghasilkan sebuah Knowledge Sharing System berbasis web yang telah diuji coba dengan menggunakan metode Black Box testing dan telah diimplementasikan pada PDAM Tirta Musi Palembang yang digunakan untuk membantu dalam pengelolaan dan pendokumentasian pengetahuan karyawan.

\section{DAFTAR PUSTAKA}

[1] C. Gunawan, 2020, "Penerapan Metode TOPSIS untuk Pengangkatan Karyawan Kontrak Menjadi Karyawan Tetap (Studi Kasus: PT Hanuraba Sawit Kencana)," JIKO (Jurnal Inform. dan Komputer), vol. 3, no. 1, pp. 42-50.

[2] C. E. Gunawan and F. Fenando, 2018, "Pengukuran Keamanan Informasi Menggunakan Indeks Keamanan Informasi (KAMI) Studi Kasus di PUSTIPD UIN Raden Fatah Palembang," JUSIFO (Jurnal Sist. Informasi), vol. 4, no. 2, pp. 121-132.

[3] M. H. Irfani, 2018, "Pengaruh Teknologi Knowledge Management Terhadap Kreativitas dalam Meningkatkan Prestasi Belajar
Mahasiswa UIN Raden Fatah Palembang," JUSIFO (Jurnal Sist. Informasi), vol. 4, no. 2, pp. $165-179$.

[4] A. Rakhmawati, 2017, "Strategi Pengelolaan Manajemen Perusahaan (Penerapan Manajemen Pengetahuan Ke Dalam Organisasi)," AlGHAZWAH, vol. 1, no. 1, pp. 29-38.

[5] A. Latief, N. Nurlina, E. Medagri, and A. Suharyanto, 2019, "Pengaruh Manajemen Pengetahuan, Keterampilan dan Sikap terhadap Kinerja Karyawan," JUPIIS J. Pendidik. ILMUILMU Sos., vol. 11, no. 2, p. 173.

[6] F. S. Jumeilah and D. I. Sensuse, 2018, "FaktorFaktor yang Mempengaruhi Proses Manajemen Pengetahuan: Studi Kasus STMIK XYZ," JUSIFO (Jurnal Sist. Informasi), vol. 4, no. 2, pp. 133-142.

[7] L. Martini, 2016, "Knowledge sharing in a creative city," Procedia Comput. Sci., vol. 99, pp. 79-90.

[8] F. Sari, R. Ruliansyah, and T. Avini, 2015, "Sistem Informasi e-Learning pada SMK 6 Palembang Berbasis Web," JUSIFO (Jurnal Sist. Informasi), vol. 1, no. 1, pp. 21-30.

[9] A. Mubarak, 2019, "Rancang Bangun Aplikasi Web Sekolah Menggunakan UML (Unified Modeling Language) Dan Bahasa Pemrograman PHP (PHP Hypertext Preprocessor) Berorientasi Objek," JIKO (Jurnal Inform. dan Komputer), vol. 2, no. 1, pp. 19-25.

[10] E. Sutrisna, 2018, "Implementasi Knowledge Management System Berbasis Website Dengan Model Spiral pada PT Trans Retail Indonesia," J. Inform. Univ. Pamulang, vol. 3, no. 2, pp. 64 74.

[11] E. Ekadiansyah, 2013, "Implementasi Knowledge Management System pada Pengembangan Sumber Daya Manusia," CSRID J., vol. 5, no. 2, pp. 102-117.

[12] T. H. . Putri, Suhitarini Soemarto; Pangaribuan, 2009, "Knowledge Managament System: Knowledge Sharing Culture di Dinas Sosial Provinsi DKI Jakarta," Semin. Nas. Apl. Teknol. Inf. 2009 (SNATI 2009), pp. 65-70.

[13] R. S. Pressman, 2009, Software Engineering A Practitioner's Approach 7th Ed - Roger S. Pressman.[14] C. E. Gunawan, M. Ramadhan, and I. Indrawan, 2013, "Sistem Informasi Seleksi Calon Mahasiswa Berbasis Web di Sekolah Tinggi Teknik Musi Palembang," JUITA J. Inform., vol. 2, no. 4. 